\title{
TEMPORAL AND SPIRITUAL SELF-RELIANCE: THE CHURCH OF JESUS CHRIST OF LATTER-DAY SAINTS AND DEVELOPMENT IN THE SOUTH PACIFIC
}

\author{
Paul Morris ${ }^{1}$
}

\begin{abstract}
The Church of Jesus Christ of Latter-day Saints (LDS Church, aka, the Mormons) plays a significant but largely neglected role in the literature on development in the Pacific. The aim of this paper is to address this lacuna and highlight the distinctive LDS theology of development without which their development agendas make little sense. The Pacific is pivotal to the LDS Church's global mission where its commitments to development, and emergency relief, have since the 1980 s been increasingly understood in terms of an overarching theology of 'self-reliance', explored here both theologically and as specifically applied in the Pacific. Two main arguments are advanced in this article. First, the LDS Church's development programmes in the Pacific have led to a re-articulation of their self-understanding and rationale and a recalibration of their Church's priorities regionally and beyond. Second, while it often seems that Mormons are wedded to the capitalist system, this is recent and they are equally heirs to another model of 'economic or gospel communalism', and that the retrieval of this tradition is consistent with the Church's priorities for the Pacific and a growing concern there.
\end{abstract}

Keywords: Christianity; development; Mormons; Pacific Islands; self-reliance

\section{INTRODUCTION}

At a conference in Suva on religion and development in the Pacific in $2016^{2}$ the chasm between our luxury hotel and the nearby shanty we visited, and the water bottling plant for export and the broken sewer main nearby, became increasingly evident. This served to highlight another glaring gap - that between religious leaders and Non-Governmental Organisations (NGOs). A regional official from the United Nations Development Programme (UNDP) praised 
the churches and religious communities for their role in the 'delivery' of UN organisations' and other NGOs' programmes, articulated in terms of their relationships of trust that provided crucial access at local levels. One Pacific church leader protested that the 'secular' NGOs' interest in the churches was limited to viewing them as 'postmen' for their programmes and ideologies, but that this usually excluded any engagement with the churches' theologies, teachings, and religious values. Over the following two days, further tensions included: theological versus technological expertise; conflicting notions of women's health, education, and morality; the continuing colonial exploitation of natural resources; and the unbalanced nature of judging development solely in terms of economic paradigms. Alongside religious and non-religious divisions, it became evident that the different churches and religious communities have divergent theologies of development, disparate partnerships and relationships with governments, NGOs, and each other, and that they play diverse roles in development itself.

Tensions such as these are intensified by the failure of some NGOs, agencies, and commentators to acknowledge the full extent of the contribution to development made by religious NGOs and Faith-Based Organisations (FBOs). There are a number of discernible phases in the transition from this widespread view to more complex and complete understandings of the roles of FBOs in development. The beginnings of this new appreciation are often dated from the recognition of the significance of religious actors for development by James Wolfensohn, then Director of the World Bank in 1998. ${ }^{3}$ While this does mark a breakthrough, their work was still largely guided by economic agendas, with religion in service to development programmes. More recently the World Bank has sought to revitalise 'its engagement with faith-based and religious organizations based on a recognition that they are often doing the essential work on the frontlines of combatting extreme poverty, protecting the vulnerable, delivering essential services and alleviating suffering. ${ }^{4}$

The last fifteen years has seen the growth of a new scholarly sub-field, religion and development, the best of which does engage with the complex roles of religious actors. However, the older dominant, economically-driven 'delivery discourse' is still evident. While the new scholarship recognises the real challenges to FBOs engaged in development from ubiquitous neo-liberal economic orthodoxies, the latter, while considering religion to be important does so, too often, by still portraying it as a barrier to be overcome, or managed, in the interests of development. ${ }^{5}$ The new consciousness of the value of religious actors in development has been coupled with a recognition that top-down, 
infrastructural, state-level development has failed to transform economies or lives as promised, thus opening a 'new development space' for FBOs to offer more local, bottom-up alternatives.

This article focusses on a single church, the Church of Jesus Christ of Latter-day Saints and their theologies of development, and how these are related to the Church's mission, with particular reference to the Pacific (Clarke 2011, 11). ${ }^{6}$ LDS Church documents, policies, guidelines, pronouncements, stake instructions, manuals, publications, and other sources are critically examined to explore the changing teachings on development, relief, and aid, and the role these play in LDs Church theologies. These are analysed in the light of the Church's past humanitarian and disaster relief policies and their implementation in the Pacific. The Church's analysis of the issues facing the Pacific that guide its work in the region are contextualised within the framework of the UN agencies, NGOs, and Pacific island governments. The argument advanced here is that the LDS Church has both engaged in development programmes, and been engaged by them, in terms of mutual impact, that has led them to rearticulate their selfunderstanding and rationale and recalibrate their Church's priorities. Outside of LDS Church sources there are no studies of this distinctive dimension of Mormon theology, or of the LDS Church and development.

THE LDS CHURCH IN THE CONTEMPORARY WORLD AND IN THE PACIFIC

The Mormon presence in the Pacific is a Church priority and a model of its missionary successes. There are sizeable populations in Hawai' i, Samoa, American Samoa, Tonga, Australia, and Aotearoa New Zealand (Morris 2015; 2018a; $2018 b$ ). Nine of the top ten countries with the highest number of Mormons per capita, led by Tonga, are in the Pacific region. The Pacific was the first overseas LDS Church mission-field and continues to play a crucial role in the LDS Church imaginary, and to be a site of substantial ongoing investment. Although small by global standards, the LDS Church is an influential regional player and makes a distinctive contribution to development in the region. The basis of this distinctiveness is the focus of this article. This Restorationist church ${ }^{7}$ has its origins in nineteenth-century America, and this identity persists, generally, and in the Pacific region, even though the majority of its members are now from Asia, South America, Africa, and the Pacific. This, in the context of the 'new development space', as defined above, coupled with the rise of academic development studies, reports of returning missionaries, and frequent calls for emergency relief, has led to the transformation of the Church's understanding of its mission and how this relates to development. 
Before turning to the LDs Church and development, it is helpful to briefly note a distinctive feature of their theologies as this bears directly on their understanding of development. Prophet Joseph Smith did not absolutely distinguish between matter and spirit, or, 'temporal and spiritual' things, and subscribed to a sort of 'spiritual materiality' that can be viewed as the rejection of a then dominant view of Platonic-Christian metaphysics, in particular, the idea that matter is the cause of evil. ${ }^{8}$ The result of this has been a focus by Mormon theologians on the physical and material, evident in the bodily emphases in developing Mormon practice and theology. ${ }^{9}$ The temporal or material becomes the foundation for the spiritual, so that until the physical needs of a Mormon and their family are catered for, a Mormon is not in a position to 'serve' others, that is, further the work of the Church.

The Book of Mormon itself, and Doctrine and Covenants, highlight the relief of the poor and advocate universal charity. In a later revelation, published in the Pearl of Great Wisdom ${ }^{10}$ Joseph Smith alludes to Enoch's perfect polity where all reside in righteousness and 'there is no poor among them'. The early Mormon pioneering travails fostered an ethic of individual, familial and communal self-sufficiency which interlaced the temporal with the spiritual reflecting this foundational characteristic of Mormon ontology. The LDS Church has been accused by outsiders of looking after their own, and its early history led to strategies and institutions to do just that. But this is better understood as a novel form of philanthropy whereby becoming a Mormon came to be understood as essential for any effective charity effort; that is, the righteous community underlies the overcoming of poverty in Zion, 'the perfected society', albeit as yet nascent as the LDS Church. In the 1830s this theology manifested itself as a form of gospel communalism, whereby those in need in the community were supported by charitable donations, and economic activity in Zion was understood as religious duty, and thus subject to the authority of the Church. In the 1840 os Smith founded the 'relief society' to provide a basis for temporal help, and since then a range of institutions have been established to work for emergency preparedness and to support struggling members. Frontier life was harsh and offering assistance to other Church members was a necessary and effective survival strategy. Responses to scarcity and deprivation promoted practical developments such as the distributive bishops' store houses from the 1870 s. $^{11}$

Tithing, initially in kind, by the beginning of the twentieth century had been replaced by cash (currently fourteen to fifteen per cent of income). While the urgency and level of support appears to have receded, the project of building 
Zion, the perfected community, is still evident. The 'Mormon millennial movement' during the nineteenth century led to more than 85,000 LDS coming from Europe, and even from New Zealand, to Utah, gathering for the 'second coming', many utilising the Church's 'Perpetual Emigration Fund' (now the Perpetual Education Fund). The 1908 Relief Society Handbook required bishops to provide work for those receiving aid, usually through local church networks. The LDS Church Relief Society responded to the 1906 San Francisco earthquake, and the First World War, by partnering with the Red Cross to support LDS families, leading to joint training and the increased professionalisation of LDS welfare. In 1936 many of these programmes came under the banner of the Church Welfare Program in response to the Great Depression, focussed on helping Church members, and potential members, including the setting up of cooperative farms or factories in stakes (several wards) with distribution coordinated via Salt Lake City, and the revival of communal fast days. The 1936 Welfare Plan was expressly designed 'to do away with the curse of idleness and abolish the evils of dole. ${ }^{12}$ In the twentieth century with restrictions on immigration to the US, the Church has increasingly 'exported' the building of Zion to Mormon converts around the world.

FROM LDS DEVELOPMENT TO THE THEOLOGY OF SELF-RELIANCE

The majority of Mormons until the Second World War lived in Utah and the adjacent states with low levels of income and wealth disparity, protected by LDS Church support. Poverty and disaster relief was delivered through Mormon networks mostly to Church members. Since 1945 the LDs Church has successfully launched global missions channelling more and more funding from the US and other developed nations to less developed LDS communities elsewhere. Responding to immediate needs in these countries, the Church has dispatched medical missionaries and those with business and other skills. There has been a redirection of projects from the US, Canada and Europe to those 'more' in need. From 1978, for example, English language teachers were dispatched to refugee camps, and since 1985 there have been fast days for those suffering famines. Since the late 1980 os the LDS Church has supported the International Red Cross and other FBOs. The exposure to development priorities beyond the needs of Church members has led to extended debates within the Mormon community about the precise relationship between members' 'development', and aid and development to those outside the Church. In 1983, Gordon Hinckley, then First Counselor, later $15^{\text {th }}$ President of the Church, explicitly reaffirmed the vision of the universal mission of salvation and the building of Zion. This commitment led to the establishment of Mormon temples around the globe, and a new and growing awareness of development programmes within this 
transnational Church, and beyond. ${ }^{13}$

The next President of the Church, Thomas S. Monson extended his predecessor's vision and pursued 'new' directions. He repositioned the morally conservative LDS Church as part of an alliance of conservative Christians, mainly evangelical Protestants, manifest in support and participation in public campaigns against same-sex marriage and abortion, and for issues such as premarital sexual abstinence and religious freedom. Monson also led his Church to greater participation in interfaith dialogue and ecumenical pursuits as a way of promoting the Church by raising its profile and establishing partnerships of recognition. Monson also increased the participation of women in Mormon missions. In 2018, the Church appointed a new President, Russell M. Nelson, who has prioritised the global nature of the Church's mission, as part of a potential and diverse religious coalition rallying against secularism and atheism. ${ }^{14}$

Monson rewrote the theology of self-reliance as the central teaching of the Church. While he claims only to have retrieved and foregrounded existing Mormon teachings, at times it is difficult to clearly delineate his recovery from actual past theologies. He was a specialist in public relations, communications and media who preached self-reliance for two decades before becoming President in 2008. Beginning in 1986, he insisted that 'Salvation can be defined by no other principle than self-reliance' (Romney 2011, cited in Monson 1986, 3). Since 2014, the LDS Church has opened more than 1,100 Self-Reliance Centres in or near stake centres. At all priesthood levels (Aaron and Melchizedek), ${ }^{15}$ self-reliance groups have been created to entrench the principles of temporal and spiritual self-reliance. Self-reliance, for example, is an integral part of the formation of the Aaronic Priesthood, for Mormon male youth, as they develop temporal skills that are designed to support themselves and their families, and learn to be spiritually self-reliant - wonderfully glossed as having spiritual experiences that 'do not depend on the testimonies of others' (ibid). There are now Self-Reliance Centres in seventy-five countries administering schemes such as the Perpetual Education Fund which has granted more than 70,000 interest-free tuition loans in more than seventy countries.

What is self-reliance? According to Monson, it is 'the ability, commitment, and effort to provide the spiritual and temporal necessities of life for self and family'; 'Self-reliance is a product of our work and undergirds all our other welfare practices. It is an essential element in our spiritual as well as temporal wellbeing'; and 'Self-reliance is a principle of salvation' (LDs Church Handbook 2 (2010, 6.1.1). Temporal welfare and relief is the only possible basis for spiritual development, allowing Mormons to focus on the material as a path to the 
spiritual. Self-reliance, spiritual and temporal, is the foundation on which the Church is established and only when this is secured at the individual and familial levels can Mormons 'serve the Lord and care for others'. Self-reliance is eminently practical and directed to each and every individual Mormon, and includes time and money management, problem solving, cooperation, communication, integrity, healthy living, and water and food storage. ${ }^{16}$ Disseminated throughout the LDS Church, the manuals My Path to Self-Reliance (2016) and My Foundation: Principles, skills, habits, and self-reliance $(2015)^{17}$ have guided hundreds of thousands of Mormons to undertake self-reliance self-assessments and gain certification for having completed temporal and spiritual self-reliance training. Self-reliance is embedded at every level: each local stake and district level have self-reliance committees, which develop and implement their stake self-reliance action plan. Self-reliance programmes for church members now embrace bishops' storehouses, employment centres, charity shops, and family and other counselling services. There is even a downloadable Mormon Channel Mobile App which includes a series focussed on Spiritual Self-Reliance, both as a source of strength for individuals and one that offers guidance for the support of others in spiritual need. Mormon women link self-reliance to women's empowerment (Madsen 2015, 68). The 2017 initiative understands self-reliance as a zero-sum game so that if self-reliance is not increased then those involved are 'more reliant'. What does all this amount to? Simply put, under Monson the LDS Church came to authoritatively re-define Mormon formation as temporal and spiritual self-reliance, incorporating temple rituals, communal structures, and church hierarchies. ${ }^{18}$

\section{SELF-RELIANCE IN THE PACIFIC}

This new self-reliance framework for LDs Church members is simultaneously the foundation for the framework for development globally. Monson was responsible for LDs programmes for the Pacific and Australia and was very aware of the realities of this region in which he had travelled extensively. His recognition of the need to transition from missionary successes to communities of self-reliance arose in large part out of his reflections on LDs Pacific experience. He organised the first stake in Tonga in 1968 and oversaw the organisational structuring of the church in Samoa.

Temporal and spiritual self-reliance now characterises the programmes for LDS members not only in the 'developed North' but in Sub-Saharan Africa, South America and Oceania. The 2016 Pacific Area Plan focussed on five objectives including increasing 'spiritual and temporal self-reliance' and hastening 'the work of salvation. The Perpetual Education Fund has been expanded and re- 
defined, and is now administered as a 'self-reliance initiative' and the impetus is to foster self-reliance among members, including seminars and training with a focus on 'self-employment' for the Pacific area. Humanitarian services in the Pacific, while subject to entirely separate administrative and financial reporting lines from the mission to Church members, are both presented under the same rubric of 'self-reliance'.

It is clear from the discussion so far, I have used 'development' in the LDS Church case to include the Church's development projects for its own members, as well as emergency aid and the prophylactic development projects subsequent to disaster relief for non-members of the Church. This is the LDs Church's understanding too. Whilst these are clearly distinct arenas, the tension between the growing universality of Zion and the LDS Church's focus on its members has long been evident in some quarters, the recent global expansion having heightened awareness of broader universal development needs.

Mormons have historically made a clear demarcation between members and those beyond the Church, often referred to as 'gentiles. ${ }^{19}$ Reflecting this distinction is that between LDS 'humanitarian aid' for non-members and the programmes and policies restricted to Church members. Humanitarian Services is a branch of their Welfare Services department, and operates LDs Charities, which aims to relieve the suffering of those in urgent need 'without regard to the nationality or religion of the recipients'; that is, almost exclusively those beyond Church membership. Services include emergency disaster relief following natural and man-made disasters (food, clothing, shelter, medical personnel and medicines, and other supplies). I visited Samoa and Tonga in 2009 after Hurricane Rene and encountered a repeated refrain from non-Mormons that (the humanitarian) help by the LDs Church was given to all those in need not just focussed on their own members. More recently disaster relief has been extended to development projects designed to support the longer-term needs of communities around the world, often in the aftermath of emergency relief. In the last two decades this humanitarian aid and development has also been framed within a discourse of helping these communities become 'self-reliant', via the provision of resources and the fostering of the acquisition of skills. The LDs Church has five global projects under the rubric of self-reliance (neonatal resuscitation, water projects, disability services, vision treatments and children's vaccinations). This area of the Church's work has steadily grown in profile since the Latter-day Saint Humanitarian Center was established in 1991 in Salt Lake City to prepare humanitarian supplies for use worldwide and train those wanting to develop employable skills to become self-reliant and foster this in others. ${ }^{20}$ 
The links between promoting self-reliance for LDS Church members, and selfreliance as the rationale behind development projects and programmes for 'all those in need' have in recent years become entangled, or at least more complex. ${ }^{21}$ So that while the principal aim of humanitarian service is 'to relieve suffering, to foster self-reliance for families of all nationalities and religions, and to provide opportunities for service', its secondary aim is to 'help bring the Church out of obscurity'. And this can potentially challenge the stringent missionary protocols and guidelines that separate missionaries working on humanitarian development projects from those actively engaged in proselytization. The Church has been vocally and consistently opposed to 'missionary aid'. As a 2012 report clarifies, 'humanitarian relief is directed to global communities and individuals not of our faith as opposed to the "Welfare Program" directed towards Saints in need'. The two are connected, in that 'After urgent needs are met the Church looks for additional ways to aid long-term goals. Our approach is always to help people become self-reliant by teaching skills and providing resources for a self-sustained life' (LDS Philanthropies 2012).

LDS Charities (Humanitarian Services, Emergency Responses, and US Community Resources) (https://www.latterdaysaintcharities.org/) was established

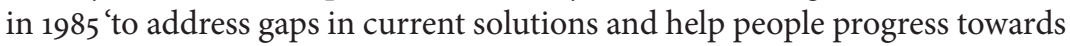
self-reliance'. In 2012 the UN granted them 'recognised NGO status'. At a Focus on Faith gathering of the Nongovernmental Organizations Relations and Advocacy Section of the UN's Department of Public Information in New York in 2014, leading LDS Church spokespersons presented,'Discovering Mormonism and Its Role in Humanitarian Assistance, ${ }^{22}$ stating, 'The primary purpose of LDS Charities is to relieve suffering, foster self-reliance, and provide opportunities for services for families of all nationalities'. It was reported that LDS Charities provided assistance to more than two million people in 132 countries (2013) and that the Church was guided by the MDGs (United Nations Millennium Developments Goals) and how closely these resonated with the values of the Church. More recently this compatibility has been extended in a systematic way to the SDGs (United Nations Sustainable Development Goals). There are sixteen area offices globally, one of which is in New Zealand. LDs Humanitarian Services is also tasked with forging partnerships with governments, NGOs and FBOs, Christian and Muslim, around the world. ${ }^{23}$ Mormon missionaries play a particular role here, both as labour for humanitarian projects and as advocates for aid and development upon returning from missions to affected areas. Brigham Young University collaborates with the LDS Church by dispatching qualified students to support their self-reliance programmes, as interns who receive academic credit. 
Mormons proudly celebrate their pioneer ancestors. The LDS Church has historically disproportionately attracted displaced and marginalised working people. While we briefly traced above the progressive embourgeoisement of the Utah community, the Church continues to convert among 'peasant families displaced to cities', largely in developing countries (Bushman 2006, 106). Mormon sacred histories of their pioneering forefathers crossing the US resonate strongly with the challenges now faced by Latter-day Saints in 'the developing world', creating points of identification and inclusion as these orienting narratives are retold and extended. In spite of this historical model, LDS missionary activities appear to be based more on the suburban ward model of the twentieth century US rather than the Mormon village ward of the nineteenth century, with the main areas of LDS growth among struggling urbanites rather than those engaged in subsistence living in rural settings. This 'suburban' model is reflected in, and shapes, the LDs Church's image and aspirations for their development endeavours.

\section{PACIFIC PROJECTS}

Turning to the Pacific itself, the LDs Church's efforts are focussed on the development of LDS members, as well as broader humanitarian projects directed to those beyond the current Church. The latter engage the Mormons in partnerships with governments, NGOs and other FBOs. The Church has acknowledged that the South Pacific has both generic development issues shared with Eastern Europe, sub-Saharan Africa and South America, but also has concerns specific to the Pacific Island nations. It has designed programmes specially to guide its work in the Pacific and made huge investments. The LDs Church contends that unlike more heavily populated areas in the world, the Pacific Islands generally include fertile lands and oceans that allow for a degree of 'self-reliance', but sustainable and 'improved' lives will require very particular interventions. The LDS Church is highly critical of government aid and remittances that they contend serve to foster dependency and an 'entitlement mentality' although this analysis is not always consistently applied. Cognisant of the technological and digital transformations that are increasingly integrating the Pacific into the global economy, the LDs Church opines that what are needed are contemporary flexible, 'first world skills' and a conscious future-orientation.

The New Zealand role in LDs development activities in the Pacific is significant, with a Church Pacific Area Welfare Manager, approximately thirty full-time missionaries and ten employees, and the Pacific Area Presidency based in Auckland. ${ }^{24}$ The priorities for the South Pacific are health, focussed on non-communicable diseases, especially diabetes, undernourishment and 
malnourishment of children, and domestic violence. Church welfare includes both medical interventions and education. Following health, the priority is on economic issues: lack of sustainable businesses, reliable and affordable energy supplies, and commercial infrastructure; again, there are both direct support and educational offerings. These are presented under the rubric of 'self-reliance' and promote self-employment. It is interesting to note that the educational materials emphasise emergency preparedness and 'provident living' including the storage of emergency supplies and resources, and while making reference to rising sea levels and cyclones, there is no discussion of climate change.

There are humanitarian and Church development projects across the Pacific. These include a 12-week training course for LDS members in Solomon Islands in concrete block making, training in manufacture, and business development, supplied by the Church. This has been successful in terms of the number of blocks made for the building sector and the numbers of those involved. Also, in Solomon Islands there have been programmes for women to produce goods for markets, mainly food and clothing. Local partners have included Caritas, Adventists, Red Cross, IsraAID, and Rotary. We will briefly explore two current LDS development projects in the Pacific, one in Tonga and the other in Vanuatu. These will indicate the theologies and structures in operation in order to explicate LDS Church development practices and highlight some of their difficulties, contradictions and successes.

\section{Project One: Tonga}

The LDS Church in Tonga has a track record of cyclone disaster relief and undertook a clean water project in Niuatoputapu. In 2014 the LDS Church (through LDs Charities Australia) formalised agreements with the Government of the Kingdom of Tonga for further provision of 'humanitarian and development assistance' (including the provision of food, water, clean up support and provision of temporary housing) to residents of Ha'apai Islands affected by Tropical Cyclone Ian earlier that year. The Church agreed to repair sixty-one houses and construct 116 new houses for residents in the islands of Ha'ano, Mo'unga'one, 'Uiha, Lifuka and Foa. The Church has built and funded 'core resistant structures', approximately five by three-and-a-half metres and 'cyclone proof' with sanitation, as the base to which other living spaces have been added. With building materials, supplies and equipment for the project funded by the LDS, 'This program is designed to foster self-reliance in addition to meeting the immense need to build new homes'. The additional rooms and facilities, amounting to half the total costs, were funded by the other partners, including the World Bank and the Tongan Government, with coordination 
undertaken by the National Emergency Management Organization (NEMO) and the Ministry of Infrastructure. ${ }^{25}$ LDS Tongan members were employed as forty-three apprentices to first work on their own houses and then to assist in the building of a set number of other dwellings.

By 2015,105 homes had been completed. ${ }^{26}$ The forty-three volunteers who had been trained, and had completed the construction project and received trade certification, were able to keep their tools, helping them to obtain in-demand construction jobs. Roughly half these students were supported by a Perpetual Education Fund (PEF) loan and have completed the Certificate Level Two going on to qualify as builders. Was this project humanitarian aid or directed to LDS Church members? Both. The rebuilding and repair of cyclone damaged houses arose out of emergency relief and by the nature of the construction were intended to provide greater self-reliance. However, the houses were mainly for Church members, even if they were for others too. The same is true, in part, for the (self-reliance) education for apprentices who worked on the building.

Currently, the LDS Church in partnership with Motivation Australia (20152020) is training medical professionals and caregivers to assess mobility needs. The Church has supplied more than five hundred wheelchairs and three hundred mobility aids, and is providing basic dental services in a number of areas in Tonga. Earlier this year the twelve LDs evacuation centres in the Ha'apai islands were utilised during Cyclone Gita. I was told that in Tonga the LDS churches and buildings were the safest places to be during a cyclone.

\section{Project Two: Vanuatu}

The LDs Church responded to Cyclone Pam in Vanuatu in 2015 with emergency 'humanitarian' relief, food, water, shelter, medical and hygiene personnel and supplies. These included 2,000 emergency family food boxes dispatched from the LDS in New Zealand. The devastation and displacement led the Church to initiate a plan for long-term secure housing as a foundation for enhanced 'self-reliance. The Church provided 'building materials, design expertise and construction oversight'. Education and training in construction ('Building Back Safe') was an integral element of the project in Port Vila arranged by LDs Charities. The aim was to rebuild houses, most of which have now been completed; additionally, hundreds of dwellings have been repaired. A portable saw mill and timber were transported to the island of Tanna in the southern Tafea province where nearly eighty houses have been built, with a further one hundred having been completed on Efate in the central province of Shefa. Hans Sorensen, the Pacific Area manager of humanitarian relief, reported that, 'Deter- 
minations as to who receives assistance rebuilding or repairing their home are made without regard to Church membership - everyone is treated equally'. On Efate and Tanna both members and non-members of the LDs Church who lost their homes and belongings were rehoused. In Vanuatu the LDs have worked cooperatively with national, local and regional governments, NGOs and FBOs. Again, it is clear that while these projects were broadly directed beyond LDS Church members, their primary focus was often on Church members.

\section{THE ROOTS OF MORMON SELF-RELIANCE}

Melvin J. Ballard was a significant figure in Mormon self-reliance initiatives of the 1930s. He led the team that divided the Church into thirteen welfare regions, each region with a storehouse and resources to produce necessities and offering temporary temporal help and opportunities of working in these programmes. His legacy has been the establishment of the Melvin J. Ballard Center for Economic Self-Reliance in 2010, housed at the Marriott School of Management at Brigham Young University, in Provo, Utah. The Center addresses the alleviation of poverty by focussing on economic self-reliance (Godfrey 2013). In part its research looks at the ways in which the LDs Church's more than $\$ 1$ billion per year in relief and other aid, since the Church Humanitarian Fund was set up in 1985, can be best utilised. In 1996 the first Mormon NGO was established and in 2001 the Perpetual Education Fund was announced. From the 1980s, the media coverage of disasters and suffering increasingly led Mormons across the 'developed' world to pressure their Church to further action. Ballard was equally interested in thinking about the societal system that would prove able and sufficient to meet needs. The humanitarian turn has led LDS scholars to return to these previous Mormon traditions of the redistribution of wealth and alternative models of ownership. The work of the Centre has raised the profile of global realities among Mormons, as has their training for Mormon development projects. These new emphases are reflected in development concerns being widely discussed and disseminated across the Church. For example, the $11^{\text {th }}$ International Society conference in 2000 was themed, 'Development Assistance and Humanitarian Aid: The LDS Perspective' where scholars brought development literature to the attention of Church decision-makers. ${ }^{27}$

Self-reliance appears quintessentially American, a romantic age value that fosters a committed individualism compatible with a capitalist system. The phrase became prominent with the publication in 1841 of Ralph Waldo Emerson's (1982) essay on self-reliance. This renowned essay calls on men to rely on their own instincts, imagination and thoughts rather than those of received wisdom, popular opinion or peer pressure: 'to believe your own thought, to believe that 
what is true for you in your private heart is true for all' (Emerson 1982, 175). He despised conformity and dependence and insisted that a man reject the lack of courage that fosters cynicism, hesitancy and an overly critical appraisal of himself in favour of individual certainty and freedom. The opposite of conformity is self-reliance. Joseph Smith and Emerson were contemporaries and were formed in the same fevered religious and social New English milieu (Brodhead 2009, 23-24). While very different, they shared a belief in an accessible spiritual realm, the potentially infinite progression of the heroic individual, the sublimity of nature and a rejection of man's fall from grace in the garden. ${ }^{28}$ Alongside Joseph Smith and Brigham Young, Emerson considered that like Adam, the first man, it was noble to grow one's food, build one's own shelter, live in the country and experience the divine in nature, as antidotes to the evils of town life. While the parallels between what became known as transcendentalism and Mormon theology should not be overstated, the rejection of classicism in favour of self-reliance loomed large in both.

Since Emerson, Mormons have both extolled and explored the limits of selfreliance and made the concept their own, transformed, albeit still recognisably Emersonian. For example, the LDS Church notion of spiritual self-reliance as having spiritual experiences that 'do not depend on the testimonies of others' strongly resonates with Emerson's 'no law can be sacred to me but that of my nature' (Hudson 2009, 202). Although for the Church this came to be tempered by a rejection of the transcendentalist's hyper-individualism that was seen to have ceased prematurely by denying that our responsibilities to ourselves need to be extended beyond ourselves to others, and our ultimate dependence on God. Self-reliance was resurrected in response to the Depression, maintained through the post-War period to be recovered anew in the $198 \mathrm{os}^{29}$

It was as late as the mid-1970s that the LDS Church left its 'enclave' and began to publicly respond to the politics of the day (Olmstead 2007). In 1982, LDs President Romney in his pivotal 'Self-Reliance' address focussed on the sanctity and necessity of work, ${ }^{30}$ the rejection of permissive indulgence and the significance of self-reliance. His exemplar of the antithesis of self-reliance was 'Soviet slavery' as he led the LDs Church to identify as a Cold War warrior. Emerson, however, is still evident in Romney's stern warning that genuine self-reliance included ensuring that Mormons did not become dependent on their church leaders. Since then Mormon self-reliance has been increasingly tied to a capitalist economic system and a set of recognisable American conservative values. The contemporary, post-Monson LDs theology of reliance, while resonating with pioneer self-reliance, plays a significantly more central role as the foundation of the Mormon formation for salvation. ${ }^{31}$ 
Like all religious traditions, LDS thought is more variegated and complex than suggested by its pyramidal hierarchy. In fact, its centralised authority paradoxically spawns its diverse viewpoints. It is a global community of debated and contested theologies. The LDS Church is publicly committed to the bringing of Zion (the Kingdom of God), but perhaps conflicted about the best way to achieve this. The dominant vision has been that Zion will be the inevitable result of the conversion of all to the true faith. ${ }^{32}$ This will come about as Mormons develop their temporal and spiritual self-reliance. Since the 1980 os this has been expressed in the LDS Church's highlighted priorities; preaching the gospel (missionaries and their proselytising activities), perfecting the Saints (achieving temporal and spiritual self-reliance and serving the Church) and the redeeming of the dead (constructing genealogical records and performing temple ordinances or baptisms of the deceased). As the LDS Church prospered in the US and beyond, these three priorities have been challenged by a new and growing priority that has arisen from the experiences of new Mormons in less developed parts of the world, and also from humanitarian and relief work, returning missionaries and the Mormon embracing of development concerns. A new priority is taking shape, supplementing the three above: an urgent caring for the poor and needy (LDS Church Handbook 2 (2010, 2.2). This new awareness of the complexities of helping and just how difficult it can be to be the 'good Samaritan' is dawning among Mormons, necessitating a rethinking of humanitarian self-reliance and bringing into relief the relationships of Church priorities and their responsibilities for global development.

CONCLUSION: THE LDS CHURCH IN THE PACIFIC

In summary, while global aid and development priorities are an escalating priority for the LDS Church, particularly in the very areas of their growth, including the Pacific, these are largely framed in terms of self-reliance understood in terms of neo-liberal free-market capitalism. And while there are surface similarities such as the material rewards for disciplined hard work, there are as many contradictions. How Mormons became so enamoured with capitalism is a recent story. Beginning with a Cold War antipathy to socialism, via the culture wars of the early 1980 os, the LDS Church became increasingly identified with moral and religious conservative agendas, and as this conservativism aligned itself with neo-liberalism, so did the Mormons, as is evident in their solid majority support for the Republican Party. ${ }^{33}$ Also, persecuted minorities develop their own version of intersectionality, so that Mormons, after nearly two centuries of persecution and marginality, are wedded to 'religious freedom' but have come to conflate this with other freedoms, such as freedom from government interference, and, of course, freedom of the market. ${ }^{34}$ 
Whilst this has mainly been directed to Church members its own logic has mandated that when LDS Saints were temporally secure, they should serve the wider community and care for its poor, and they continue to do just that. While the benefits of self-reliance are evident, the capitalist orientation obscures the structural conditions (and climate change) that continue to generate poverty and need, in contrast to the structural solutions advocated by their own creative forefathers. While Zion was initially transplanted from the Land of Israel to Utah it has since become globalised. The tensions I have highlighted above are not irresolvable and the coming of universal Zion and Church welfare can work in tandem. The LDS Church has developed over nearly two centuries innovative traditions of 'consecration'; ${ }^{35}$ of collective ownership and responsibility, a sort of gospel communalism that offers alternatives to Protestant and liberal individualism and neo-liberal capitalism. ${ }^{36} \mathrm{~A}$ greater balance between these noble traditions and current priorities may advance the fulfilment of the coming of Zion.

The LDS Church's successes in the Pacific in terms of the percentages of Mormons in the populations of countries such as Tonga and Samoa have led to the Pacific becoming seen as a paradigm for successful Mormon missions globally. Tonga, and to a lesser extent Samoa, continue to provide missionaries across the Pacific and beyond, and Pacific development projects have been replicated elsewhere.

The LDS Church in the Pacific has a very particular profile, whereas the burgeoning 'new' Mormons of sub-Saharan Africa and South America are mainly rural migrants to the towns and cities, those of the Pacific are still linked to villages or much smaller conurbations. The Church has long recognised distinctive Pacific social hierarchies, relationships and traditions and sought to leverage these, and Pacific Mormon communities continue to reflect local social and cultural practices. These often create tensions within the LDS Church and beyond. My fieldwork in the Pacific indicates that Saints report considerable tensions over a range of traditional matters. In Samoa, for example, there are concerns over tattooing, kava, participation in fono councils, and over the prioritising of the nuclear family over the aiga (the extended Samoan family unit defined by those who acknowledge the aiga's chief or matai). Discussing these issues with Pacific Saints there is a growing interest in the discourse on mutual help and supportive self-reliance, that has persisted alongside the celebration and embracing of neo-liberal capitalism. The Church's adherence to participation in a late capitalist global market system often cannot be easily or simply applied in Pacific contexts. Successful projects have often worked in more communal ways addressing collective rather than individual concerns 
and thus have begun to effectively address structural issues of poverty and need. The LDs Church's actual experience in the Pacific rather than its ideological models have impacted on the shaping of these development projects and priorities and could be perceived as highlighting past LDS teachings. The Pacific LDS Saints have maintained traditional social patterns that have provided both the strength and growth of their communities and generate increasing tensions between their experiences and implicit values and those of the neo-liberal version of self-reliance.

The retrieval of these erstwhile Mormon traditions may better allow Pacific Latter-day Saints to engage with the consequences of climate change and other structural impacts of global market arrangements and foster a nearly lost model of Mormon 'self-reliance', one relevant to the future of the Church itself. Just as appreciation of LDS theologies of development fosters greater understanding of LDS development agendas. This is the case for other FBOs allowing the bridging of the gaps between churches and other FBOs and between FBOs and NGOs and governments as they work alongside each other for the development of the Pacific region.

NOTES

1 Paul Morris is Emeritus Professor of Religious Studies at Victoria University of Wellington. A specialist in the field of contemporary world religions, his publications explore religious change in the Pacific, religion in New Zealand, religion and politics, cosmopolitanism and Jewish religious thought.

Email: paul.morris@vuw.ac.nz

2 Pacific Theological College (PTC) hosted the G2o Pacific Regional Conference, May, 2016.

3 For the official World Bank narrative, see Marshall (2001). On FBOs from the perspective of the World Bank initiative, see Marshall and Keough (2005); Marshall and Van Saanen (2007); Marshall and Bhagat (2008); and Rees (2011).

4 Former World Bank President, Jim Yong Kim, spearheaded a revitalisation of the World Bank's relationships and partnerships with FBOs (2014). See http://www. worldbank.org/en/about/partners/brief/faith-based-organizations.

5 See Fountain, Bush and Feener (2015); also, Swart and Nell (2016); Tomalin (2015); Rakodi (2014); Smith (2017); de Kadt (2009); Ware and Clarke (2016); Carbonnier (2013); Tomalin (2013); and Clarke and Ware (2015). 
6 I write as a non-LDs scholar with academic interests in religious change in the Pacific. My wider research has brought me into contact with LDS Saints, their scriptures and solidarities, and the dearth of studies of their Pacific development agendas and theologies led to the research for this article.

7 Restorationism is the name given to churches that attempt to restore Christianity to what they understand to be the true and original beliefs and practices of the earliest apostolic church.

8 See McMurrin $(1993,36)$ : 'All spirit is matter, but it is more fine or pure, and can only be discerned by purer eyes' (Doctrine and Covenants 131:7, Book of Mormon | Doctrine and Covenants | Pearl of Great Price (Salt Lake City, Utah: Church of Jesus Christ of Latter-day Saints, 2013, 233). See also, Nolan (1989).

9 For an erudite discussion of Mormon materialism as a rejection of traditional Christian metaphysics, see, Webb (2011); for a discussion of the debates within the LDS, see Reeves (2012).

10 Book of Mormon | Doctrine and Covenants | Pearl of Great Price (Salt Lake City, Utah: Church of Jesus Christ of Latter-day Saints, 2013.

11 President Heber J. Grant argued that 'Nothing destroys the individuality of a man, a woman, or a child as much as the failure to be self-reliant' (Relief Society Magazine, October 1937, 627), https://www.churchofjesuschrist.org/study/generalconference/1991/10/becoming-self-reliant?lang=eng.

12 The quotation is from October 1936 when the then LDs Church president, Heber J. Grant, announced the new welfare programme, quoted in Given and Reid (2014, p194). For details of the 1936 Welfare Plan, see Arrington and Hinton (1964); Arrington, Fox and May (1992, 337-358); Mangum and Blumell (1993).

13 See 'Full text: President Hinckley's speech at the National Press Club', Deseret News 27 March 2000, https://www.deseretnews.com/article/155008580/Full-textPresident-Hinckleys-speech-at-the-National-Press-Club.html

14 https://www.abc4.com/news/local-news/changes-made-since-russell-nelsonbecame-president-of-the-latter-day-saints-church/.

15 After the age of twelve LDs Church males can be ordained to the Aaronic priesthood by the laying on of hands by male priests and use the title 'elder'. To be admitted to the Melchizedek priesthood, a male must be an Aaronic priest and 
be over eighteen, and can use the title 'high priest', ordain others and serve the Church as bishops, stake president, mission president, or temple president.

16 All Is Safely Gathered In: Family Home Storage (2007) updates and resets the older emergency food and water storage with new processes and includes financial savings as part of emergency readiness.

17 See also The Leader's Guide for the Self-Reliance Initiative (2017).

18 For a popular Mormon theology portraying self-reliance, see Connor Boyack (2012).

19 Mormons that I have consulted consider themselves as 'Israel', like other forms of Christian Israelitism, and while understanding gentiles to have an essential part to play in the 'latter days', do not count Jews as gentiles.

20 In 2006 I visited this Centre which offers training to interns from around the world to work on projects in their own regions.

21 See 'Let us be Self-Reliant and Independent' (2017), which discusses the use of missionary and non-missionary support for 'struggling Saints' and broader projects.

22 The LDs Church has undertaken many such addresses, for example, Jeffrey R. Holland spoke at the House of Lords, British Parliament, in 2015 on 'Religious Conflict: Can Humanitarian Aid Help?' LDs Church representatives included Sharon Eubank, director of Humanitarian Services and LDs Charities, Ahmad Corbitt, and Phil Colton, a nuclear scientist. The LDs Church and nuclear power and waste is a revealing, important, and understudied subject beyond the scope of this paper.

23 For current partnerships with FBOs and NGOs, UN and government agencies, see LDS Charities Annual Report $(2018,5)$; in 2017, there were 2705 projects with 1800 partners in 139 countries.

24 The eight Service Centres (the temporal affairs offices of the presiding bishoprics) report to the Pacific Area Office in Auckland.

25 See Government of Tonga 2015-2016 Budget Statement $(2015,6)$ for details of LDS building and rebuilding. 
26 The work was managed by Tongan contractor, Oregon Pacific International, for details see http://projects.worldbank.org/procurement/ contractoverview?lang=en\&contr_id=1522556\&

27 See Development Assistance and Humanitarian Aid: The LDs Perspective (2001) for papers and discussion.

28 On the romantic in Emerson and Smith, see Park (2010).

29 Besides numerous references to Emerson's self-reliance by LDS Church spokesmen, Emerson's argument for revelation in the contemporary not only in the past is a favoured text; see, for example, Jeffrey R. Holland $(2004,8)$. Both Smith and Emerson were drawn to Swedenborg's romantic theology.

30 Harold Bloom $(1992,103)$ referred to Mormons as 'perhaps the most work addicted culture in religious history'.

31 A second literary reference favoured by LDs Church leaders is Samuel Smiles and his Victorian best-seller, Self-Help (Smiles 2008 [1859]). Self-Help echoes many of their own virtues and continues to be cited and quoted. The LDs Church just as with Emerson have made him their own.

32 Although it should be noted that the LDS Church has a permissive if stratified version of the heavenly afterlife.

33 Campbell, Green, and Monson (2014, 77-102).

34 Interestingly self-reliance is connected to these freedoms: 'Whenever we get into situations which threaten our self-reliance, we will find our freedoms threatened as well' (1991).

35 A series of innovative economic arrangements were developed in the nineteenth century including the 'United Order' or 'United Firm', based on the principles of consecration; see Perry (1991). These experiments alluded to 'communitarian' or 'apostolic economics' of the biblical post-Pentecostal community.

36 In Mormon scriptures, the Nephites are corrupted by materiality and prosperity. 


\section{REFERENCES}

Arrington, Leonard, and Wayne Hinton. 1964. 'Origin of the Welfare Plan of the Church of Jesus Christ of Latter-day Saints. BYU Studies Quarterly 5 (2): 67-85.

Arrington, Leonard, Feramorz Y. Fox, and May Dean. 1992. Building the City of God: Community and Cooperation among the Mormons, Urbana, Ill.: University of Illinois Press.

Bloom, Harold. 1992. The American Religion: The Emergence of the Post-Christian Nation. New York: Simon \& Schuster.

Boyack, Connor. 2012. Latter-day Responsibility: Choosing Liberty through Personal Accountability. Springville, Utah: Cedar Fort.

Brodhead, Richard H. 2009. 'Prophets in America circa 1830: Ralph Waldo Emerson, Nat Turner, Joseph Smith' In Joseph Smith, Jr.: Reappraisals After Two Centuries, edited by Reid L. Neilson and Terryl L. Givens, 13-30. New York: Oxford University Press.

Bushman, Claudia. 2006. Contemporary Mormonism: Latter-day Saints in Modern America. Westport, CT: Praeger.

Campbell, David E., John C. Green, and J. Quin Monson. 2014. Seeking the Promised Land: Mormons and American Politics. Cambridge: Cambridge University Press.

Carbonnier, Gilles, ed. 2013. International Development Policy: Religion and Development New York: Palgrave Macmillan.

Clarke, Matthew, and Vicki-Anne Ware. 2015. 'Understanding Faith-based Organizations: How FBOs are contrasted with NGOs in International Development Literature'. Progress in Development Studies 15 (1):37-48.

Clarke, Matthew. 2011. Development and Religion: Theology and Practice. Cheltenham: Edward Elgar.

de Kadt, Emanuel. 2009. 'Should God Play a Role in Development?' Journal of International Development 21(6):781-786.

Emerson, Ralph Waldo. 1982. 'The Essay on Self-Reliance.' In Ralph Waldo Selected 
Essays, 175-203. Harmondsworth: Penguin.

Faust, James E. 1999. 'Hope, an Anchor of the Soul'. Ensign (November):59-60.

Fielden, Kenneth. 1968. 'Samuel Smiles and Self-Help'. Victorian Studies 12 (2):155176.

First Presidency. 2007. All Is Safely Gathered In: Family Home Storage. Salt Lake City: The Church of Jesus Christ of Latter-day Saints.

Fountain, Philip, Robin Bush, and R. Michael Feener, eds. 2015, Religion and the Politics of Development. New York: Palgrave Macmillan.

Given, Terryl, and Reid Neilson, eds. The Columbia Sourcebook of Mormons in the United States. New York: Columbia University Press, 2014.

Godfrey, Paul C. 2013. More than Money: The Five Forms of Capital to Create Wealth and Eliminate Poverty. Stanford: Stanford Business Books.

Government of Tonga. 2015. Government of Tonga 2015-2016 Budget Statement. Nuku'alofa: Ministry of Finance and National Planning, Tonga.

Grant, Heber J. 1972. 'The Nobility of Labor'. Ensign (March): 68-71.

— 1937. 'Address'. Relief Society Magazine (October): 627.

Hasan, Rumy. 2017. Religion and Development in the Global South. New York: Palgrave Macmillan.

Holland, Jeffrey R. 2004. 'Prophet, Seers and Revelators'. Ensign (November): 8.

Hudson, Wayne. 2009. 'The Prophethood of Joseph Smith'. In Joseph Smith, Jr.: Reappraisals after Two Centuries, edited by Reid L. Neilson and Terryl L. Givens, 201-208. New York: Oxford University Press.

International Society. 2001. Development Assistance and Humanitarian Aid: The LDs Perspective. Provo: David M. Kennedy Centre for International Studies, Brigham Young University.

Jarvis, Adrian. 1997. Samuel Smiles and the Construction of Victorian Values. Stroud: Sutton. 
LDS Church. 2010. LDs Church Handbook 2: Administering the Church. Salt Lake City: The Church of Jesus Christ of Latter-day Saints.

- 2015. My Foundation: Principles, Skills, Habits, and Self-reliance. Salt Lake City: The Church of Jesus Christ of Latter-day Saints.

- 2016. My Path to Self-Reliance. Salt Lake City: The Church of Jesus Christ of Latter-day Saints.

-2017. The Leader's Guide for the Self-Reliance Initiative. Salt Lake City: The Church of Jesus Christ of Latter-day Saints.

- 2018. LDS Charities 2017 Annual Report. Salt Lake City: LDS Church: The Church of Jesus Christ of Latter-day Saints.

LDS Philanthropies. 2012. 'Humanitarian Aid and Welfare Services: A Breakdown of Donations and Resources'. Accessed 1 August 2018 from https://www. ldsphilanthropies.org/humanitarian-services/news-features/humanitarianaid-and-welfare

Madsen, Susan R. 2015. 'Latter-day Saint Women and Leadership: The Influence of their Religious Worldview'. Journal of Leadership Education 15 (2):58-73.

Mangum, Garth and Blumell, Bruce. 1993. The Mormons' War on Poverty: A History of LDS Welfare, 1830-1990, Salt Lake City: University of Utah Press.

Marshall, Katherine. 2001. 'Development and Religion: A Different Lens on Development Debates'. Peabody Journal of Education 76 (3-4):339-375.

Marshall, Katherine, and Alisha Bhagat. 2008. Challenges of Change: Faith, Gender, and Development. Washington, DC: Berkley Centre for Religion, Peace and World Affairs, Georgetown University.

Marshall, Katherine, and Lucy Keough. 2005. Finding Global Balance: Common Ground between the Worlds of Development and Faith. Washington, DC: World Bank.

Marshall, Katherine, and Marisa Van Saanen. 2007. Development and Faith: Where Mind, Heart, and Soul Work Together. Washington DC: World Bank.

McMurrin, Sterling M. 1993. 'Some Distinguishing Characteristics of Mormon 
Philosophy'. Sunstone (March):35-46.

Monson, Thomas S. 1986. 'Guiding Principles of Personal and Family Welfare'. Ensign (September):3.

Morris, Paul. 2015. 'Polynesians and Mormonism: The Church of Jesus Christ of Latter-day Saints in the "Islands of the Sea". Nova Religio: The Journal of Alternative and Emergent Religions 18 (4):83-101.

- 2018a. 'Samoa'. In Encyclopaedia of Christianity in the Global South edited by Mark A. Lamport, 698-701. Lanham, MD: Rowman \& Littlefield.

- 2018b. 'Tonga'. In Encyclopaedia of Christianity in the Global South edited by Mark A. Lamport, 803-805. Lanham, MD: Rowman \& Littlefield.

Nolan, Max. 1989. 'Materialism and the Mormon Faith'. Dialogue 22 (4): 62-75.

Olmstead, Jacob W. 2007. 'The Mormon Hierarchy and the MX' Journal of Mormon History 33 (3):1-30.

Park, Benjamin E. 2010. “Build Therefore, Your Own World”: Ralph Waldo Emerson, Joseph Smith, and American Antebellum Thought'. Journal of Mormon History $36(1): 41-72$.

Perry, L. Tom. 1991. 'Becoming Self-Reliant'. Accessed on 1 August 2018 from www. lds.org/general-conference/1991/10/becoming-self-reliant?lang=eng

Pew Research Center. 2012. 'Americans Learned Little About the Mormon Faith, But Some Attitudes Have Softened'. Washington, DC: Pew Forum on Religion and Public Life. http://www.pewforum.org/2012/12/14/attitudes-towardmormon-faith/

Rakodi, Carole, ed. 2014. Religion, Religious Organisations and Development. New York: Routledge.

Rees, John A. 2011. Religion in International Politics and Development: The World Bank and Faith Institutions. Cheltenham: Edward Elgar.

Reeves, Aaron S. 2012. 'Embodiment in Mormon Thought: Ambiguity, Contradiction and Consensus'. International Journal of Mormon Studies 5:139-164. 
Romney, Marion. 1982. 'The Celestial Nature of Self-Reliance'. Ensign (November): 93 .

Smiles, Samuel. 2008 [1859]. Self-Help; with Illustrations of Character and Conduct. Oxford: Oxford University Press.

Smith, Gregory. 2012. 'Mormons in America Certain in Their Beliefs, Uncertain of Their Place in Society'. Washington, DC: Pew Forum on Religion and Public Life. http://assets.pewresearch.org/wp-content/uploads/sites/11/2012/o1/ Mormons-in-America.pdf

Smith, Jonathan D. 2017. 'Positioning Missionaries in Development Studies, Policy, and Practice. World Development 9o (1):63-76.

Stark, Rodney. 2005. The Rise of Mormonism. New York: Columbia University Press.

Swart, Ignatius, and Elsabé Nell. 2016. 'Religion and Development: The Rise of a Bibliography', HTS Teologiese Studies/Theological Studies 72 (4):1-27. https:// hts.org.za/index.php/HTs/article/view/3862

Tomalin, Emma. 2013. Religions and Development. New York: Routledge.

Tomalin, Emma, ed. 2015. The Routledge Handbook of Religions and Global Development Abingdon: Routledge.

Uchtdorf, Dieter Friedrich. 2011. 'Providing in the Lord's Way'. https://www.lds.org/ general-conference/2011/10/providing-in-the-lords-way?lang=eng

Ware, Anthony, and Matthew Clarke, eds. 2016. Development across Faith Boundaries. New York: Routledge.

Webb, Stephen. 2013. Mormon Christianity. Oxford: Oxford University Press.

Webb, Stephen. 2011. Jesus Christ, Eternal God: Heavenly Flesh and the Metaphysics of Matter. Oxford: Oxford University Press. 